\title{
Growth and Yield Response of Sweet Corn (Zea Mays Saccharata Sturt) on Some Green Manure Tithonia Diversifolia and Dose of EM4
}

\author{
Anastasia Maya Lestari Sinambela, Bilman Wilman Simanihuruk, Widodo* \\ Department of Crop Production, Faculty of Agriculture, University of Bengkulu \\ WR Supratman St, Kandang Limun, Bengkulu 38371, Indonesia
}

\section{ARTICLE INFO}

Keywords:

Tithonia,

EM4,

sweet corn.

\section{Article history:}

Received: July 24, 2018

Accepted: Nov 23, 2018

*Corresponding author:

E-mail: widodo@unib.ac.id

\begin{abstract}
Soil fertility decline as a result of the use of inorganic fertilizers. Tithonia diversifolia is an green manure and EM4 is a mixture of beneficial microorganisms. Application of Tithonia and EM4 on sweet corn is an effort to replace the use of inorganic fertilizers. This study aims to obtain the interaction in application of Tithonia and EM4, to compare at different doses of green manure Tithonia, and to compare on the application of multiple doses of different EM4. Completely Randomized Block Design is used which consist of two factors. The first factor is the dose of Tithonia consisting of: 0 tons ha-1, 10 tons ha-1, 20 tons ha- 1 and 30 ton ha- 1 . The second factor is the dose EM4 comprising: $0 \mathrm{ml} \mathrm{L}-1,10 \mathrm{ml} \mathrm{L}-1$ and $20 \mathrm{ml} \mathrm{L}-$ 1 of water. The results showed that Tithonia diversifolia and EM4 have no effect on the growth and yield of sweet corn. Tithonia diversifolia of 30 tons ha-1 provide the highest plant height and the highest number of leaves and and the largest stem diameter and the highest level of leaf greenish. There is a tendency on the ascending EM4 dosage, will increase the average plant height, leaf number, stem diameter and leaf greenish level.
\end{abstract}

\section{INTRODUCTION}

Sweet corn crop cultivation include spacing, watering, weeding, pest control and fertilization. Fertilization either used organic or inorganic fertilizers, but commonly farmers use inorganic fertilizers. Currently inorganic fertilizers besides expensive are also hard to gain and have a negative effect when used continuously. To replace inorganic nutrients can be done using a fertilizer derived from weed Tithonia diversifolia.

Biomass fresh weight of Tithonia reach $9^{-1} 1$ ton $\mathrm{ha}^{-1}$ when is grown over the dry season and $14^{-1} 8$ ton $\mathrm{ha}^{-1}$ during the rainy season. Tithonia diversifolia contains 3.50 to $4.00 \% \mathrm{~N}, 0.35$ to $0.38 \% \mathrm{P}, 3.50$ to $4.10 \% \mathrm{C}, 0.59 \% \mathrm{Ca}$ and $0.27 \% \mathrm{Mg}$ (Lestari, 2016). According to Hakim et al., (2008), applying Tithonia can increase the productivity of land due to lowering $\mathrm{Al}$, as well as increase the soil $\mathrm{pH}$, organic matter, the content of $\mathrm{N}, \mathrm{P}, \mathrm{K}, \mathrm{Ca}$ and $\mathrm{Mg}$ soil, thereby increasing the productivity of the plant.

Study of Lestari (2016), application of fresh Tithonia 3-4 tonnes $\mathrm{ha}^{-1}$ reduce the use of inorganic fertilizers and improve the growing media, as well as result in soybean weight up to 1.94 tonnes $\mathrm{ha}^{-1}$. The content of $\mathrm{C} / \mathrm{N}$ ratio of weed Tithonia is 8.64 . The $\mathrm{C} /$ $\mathrm{N}$ ratio of Tithonia is lower which worth to be made into green manure (Dahlianah, 2014). To speed up the process of decomposition of weed Tithonia are made in the green manure can be done with the EM4.

Simatupang research (2014), showed that the dose Tithonia compost 20 tons ha ${ }^{-1}$ given to cauliflower plants produce a high growth rate, the number of leaves, and the highest leaf dry weight compare to doses below it $\left(0.5\right.$ tons $\mathrm{ha}^{-1)}$. Ghifari et al., (2014), also stated that the treatment of cow dung compost $75 \%\left(14.12\right.$ tons $\left.\mathrm{ha}^{-1}\right)$ and Tithonia $25 \%(1,335$ tons $\mathrm{ha}^{-1}$ ) has a number of fruit and fruit fresh weight were higher on curls peppers when compared to other treatments with the potential harvest of 2,904 tons $\mathrm{ha}^{-1}$.

Phabiola researchs (1997) showed that the effect of EM4 and NPK fertilization on P uptake and rice growth on Andisol soil showed that EM4 have very significant effect on all the observed growth and production parameters: the number of tillers, plant height, stem fresh weight, available $\mathrm{P}$ levels and shoots. The highest soil $\mathrm{CO} 2$ production compared with other treatments.

Study of Purnama (1998), shows the influence of the concentration of EM4 and source of organic

ISSN: $1410-3354$ / e-ISSN:2615-7136

Cited this as: Sinambela, A.M.L, B.W. Simanihuruk, Widodo. 2018. Growth and yield response of sweet corn (Zea mays saccharata Sturt) on some green manure Tithonia diversifolia and EM4 doses. Akta Agrosia 21(2): 61-66 
material on the growth and yield of garlic (Allium sativum L.) that the interaction between treatment EM4 to the type of source of organic material have significant to very significant effects on all the observed variables: plant height, leaf area, root stem circumference, fresh tuber weight, the weight of oven dried tubers and harvest index. The interaction of rice straw treatment as source of organic material and EM4 concentration of 5,000 ppm, resulted in better growth and yield of garlic.

The objectives of this study are to obtain the interaction doses of green manure Tithonia diversifolia and EM4 on the growth and yield of sweet corn, to compare the growth and yield of sweet corn at different doses of green manure Tithonia diversifolia, and to compare the growth and yield of sweet corn on the apply of multiple doses of EM4.

\section{MATERIALS AND METHODS}

The experiment was conducted December 2016 to April 2017 at Kandang Limun Village, Subdistrict of Muara Bangkahulu, Bengkulu City with Ultisol. Furthermore corn seed used was Lorenza F1 varieties. Plot wide used was $7.3 \mathrm{~m}^{2}$ obtaining 35 holes per plot.

Determining plant samples by random, in each plot contained 5 plants as a plant samples instead of the edge plants. EM4 application conducted twice on sweet corn crop at 2 and 5 weeks after planting which is each of half part of concentration.

Inorganic fertilizer is only given $50 \%$ of recommendations. According Nurmegawati et al., (2015) a dose of recommendations for sweet corn crop are urea $350 \mathrm{~kg} \mathrm{ha}^{-1}$, SP- $36125 \mathrm{~kg} \mathrm{ha}^{-1}$ and $\mathrm{KCl}$ $100 \mathrm{~kg} \mathrm{ha}^{-1}$. Urea is given three times, namely $1 / 3$ part together with SP-36 and $\mathrm{KCl}$ at planting, $1 / 3$ part is given at the age of 21 days after planting, and $1 / 3$ part given at 35 days after planting.

All data collected from field were subjected to analysis of variance according to the procedure for complete randomized block designs. Means from individual biomass were compared using Duncan Multiple Range Test 5\%.

\section{RESULTS AND DISCUSSION}

Implementing The study was conducted from December until April 2017 in Sub District of Muara Bangkahulu, Bengkulu city on Ultisol. Planting date of sweet corn was on January 16, 2017.

Fertilization is carried out on the age of the plant's first 1 wap (week after planting) or on January 23,2017 , but at 25 of Januari 2017 rains started early days, as well as in the second fertilization is at 5 wap or February 20th 2017, dated January 25, 2017 it was raining. At the time of corn aged 4-5 wap green locusts attacks (Atractomorpha crenulata) which attack the leaves of sweet corn plant, then carried the locusts pest control measures are chemically by spraying insecticides and damage can be suppressed.

Harvesting is done 2 times a harvest where the first harvest is done at the age of plant and harvest 90 dap second at 100 dap. Harvest is done by 2 times for some corn plant that has not been possible for a decent harvest so it must wait for a few days. Harvesting is done with the criteria of the corn crop has brown hair and dry, the color of husk is still green, if grain is pressed still concentrated discharge.

\section{Results of Analysis Variant}

The research data obtained was analyzed using Analysis of Variance (Anova) by $\mathrm{F}$ test at level 5\%. The variables that significantly then tested further by Duncan multiple range test (Duncan Multiple) at level $5 \%$, Variance analysis results are presented in Table 1 are intended to see the effect of the treatment of the observed variables.

Green manure treatment of weed Tithonia diversifolia on the growth of sweet corn significantly effect on plant height at age 2 wap, 3 wap, wap 4, 5 and 6 wap, number of leaves at 3 wap, 4 wap, stem stem circumference 2 wap, 3 wap, 4 wap, 5 wap and 6 wap, level greenish leaves at 4 wap, while there is no real effect on the fresh weight of the plants, plant dry weight, the weight of cob per plot, weight of cob without husk, cob stem circumference, cob length, number of grains per ear and weight cobs ha ${ }^{-1}$.

Application of EM4 on maize have no real effect on all variables were observed, as well as the

Table 1. Summary of F-calculated values for the treatment of Tithonia diversifolia and EM4 doses on the observation variables of growth and yield of sweet corn

\begin{tabular}{|c|c|c|c|}
\hline \multirow[b]{2}{*}{ Variable } & \multicolumn{3}{|c|}{ F hitung $5 \%$} \\
\hline & $\begin{array}{l}\text { Tithon } \\
\text { ia }\end{array}$ & EM4 & $\begin{array}{l}\text { Interact } \\
\text { ion }\end{array}$ \\
\hline \multicolumn{4}{|l|}{ Plant height } \\
\hline 2 wap & $4.10^{*}$ & $0.91^{\mathrm{ns}}$ & $0,69^{\mathrm{ns}}$ \\
\hline 3 wap & $4.41^{*}$ & $0.24^{\mathrm{ns}}$ & $0,93^{\mathrm{ns}}$ \\
\hline 4 wap & $5.64^{* *}$ & $0.60^{\mathrm{ns}}$ & $0,92^{\mathrm{ns}}$ \\
\hline 5 wap & $4.05^{*}$ & $0.36^{\mathrm{ns}}$ & $0,72^{\mathrm{ns}}$ \\
\hline 6 wap & $3.12^{*}$ & $0.36^{\mathrm{ns}}$ & $0,58^{\text {ns }}$ \\
\hline \multicolumn{4}{|l|}{ Leaf number } \\
\hline 2 wap & $1.99^{\mathrm{ns}}$ & $0.84^{\mathrm{ns}}$ & $0,63^{\mathrm{ns}}$ \\
\hline 3 wap & $3.52^{*}$ & $0.64^{\mathrm{ns}}$ & $0,91^{\mathrm{ns}}$ \\
\hline 4 wap & $3.17^{*}$ & $0.50^{\mathrm{ns}}$ & $0,68^{\text {ns }}$ \\
\hline 5 wap & $1.10^{\mathrm{ns}}$ & $0.31^{\mathrm{ns}}$ & $0,41^{\text {ns }}$ \\
\hline 6 wap & $2.07^{\mathrm{ns}}$ & $0.05^{\mathrm{ns}}$ & $0,46^{\mathrm{ns}}$ \\
\hline 7 wap & $2.25^{\mathrm{ns}}$ & $0.07^{\mathrm{ns}}$ & $0,17^{\mathrm{ns}}$ \\
\hline \multicolumn{4}{|l|}{ Stem circumference } \\
\hline 2 wap & $4.63^{*}$ & $0.26^{\mathrm{ns}}$ & $0,66^{\mathrm{ns}}$ \\
\hline 3 wap & $3.76^{*}$ & $0.09^{\mathrm{ns}}$ & $0,69^{\text {ns }}$ \\
\hline 4 wap & $5.16^{* *}$ & $0.16^{\mathrm{ns}}$ & $0,76^{\mathrm{ns}}$ \\
\hline 5 wap & $3.80^{*}$ & $0.16^{\mathrm{ns}}$ & $0,61^{\mathrm{ns}}$ \\
\hline 6 wap & $3.38^{*}$ & $0.21^{\mathrm{ns}}$ & $0,53^{\mathrm{ns}}$ \\
\hline \multicolumn{4}{|l|}{ Leaf greenish level } \\
\hline 2 wap & $2.44^{\mathrm{ns}}$ & $0.47^{\mathrm{ns}}$ & $0,49^{\mathrm{ns}}$ \\
\hline 3 wap & $3.62^{*}$ & $0.16^{\mathrm{ns}}$ & $0,38^{\text {ns }}$ \\
\hline 4 wap & $0.54^{\mathrm{ns}}$ & $0.18^{\mathrm{ns}}$ & $0,17^{\text {ns }}$ \\
\hline 8 wap & $0.44^{\mathrm{ns}}$ & $0.08^{\mathrm{ns}}$ & $0,18^{\text {ns }}$ \\
\hline Plant fresh weight & $1,39^{\mathrm{ns}}$ & $0.23^{\mathrm{ns}}$ & $0.80^{\text {ns }}$ \\
\hline Plant dry weight & $1,56^{\mathrm{ns}}$ & $0.30^{\mathrm{ns}}$ & $0.81^{\mathrm{ns}}$ \\
\hline Cob weight per plot & $1,44^{\mathrm{ns}}$ & $0.45^{\mathrm{ns}}$ & $0.49^{\mathrm{ns}}$ \\
\hline Cob weight w/o husk & $1,45^{\mathrm{ns}}$ & $0.48^{\mathrm{ns}}$ & $0.64^{\mathrm{ns}}$ \\
\hline $\begin{array}{l}\text { Cob stem circumfer- } \\
\text { ence }\end{array}$ & $0,95^{\mathrm{ns}}$ & $1.07^{\mathrm{ns}}$ & $1.09^{\mathrm{ns}}$ \\
\hline Cob length & $1,79^{\mathrm{ns}}$ & $0.43^{\mathrm{ns}}$ & $0.67^{\mathrm{ns}}$ \\
\hline Seed numbers per cob & $0,97^{\mathrm{ns}}$ & $0.36^{\mathrm{ns}}$ & $0.93^{\mathrm{ns}}$ \\
\hline
\end{tabular}


interaction between Tithonia diversifolia and EM4 also have no real effect on all variables observation.

\section{Effect of green manure Tithonia diversifolia on Sweet Corn Plant Growth.}

Plant height is one of the important variables plant growth. Plant height describe the level of plant growth that can be useful in augmenting the weight of sweet corn plants as a form of growth rate, which states whether or not the disruption of sweet corn (Sigalingging, 2016). The results of analysis of variance of Tithonia diversifolia dosage and EM4 concentration of plant height showed significant variables (Table 2) that was followed by a further test DMRT at 5\% level can be seen in Table 3. presumably the higher organic matter content Tithonia diversifolia capable of increasing the water supply for the needs of the sweet corn crop. This is consistent with the statement (Naldo, 2011), that the organic material can also improve the water supply for the needs of the plant, because the organic material can absorb and store water beyond its own weight. It is also stated by Hutomo et al., (2015), that with the ability to store water Tithonia diversifolia can increase soil moisture, affect the growth of sweet corn crops. The role of water as a solvent of nutrients in the soil causing plants sweet corn easily take the nutrient as a foodstuff through the roots. Organic material also serves as a source of energy for microbes (Nugroho et al., 2013).

Table 2. Effect of dosages of Tithonia diversifolia and EM4 on the mean height of sweet corn plants at 2. 3 . 4. 5. and 6 wap.

\begin{tabular}{|c|c|c|c|c|c|}
\hline \multirow{2}{*}{ Treatment } & \multicolumn{5}{|c|}{ Average } \\
\hline & 2wap & 3 wap & 4wap & 5wap & 6wap \\
\hline \multicolumn{6}{|c|}{ Tithonia diversifolia } \\
\hline \multicolumn{6}{|l|}{ Doses } \\
\hline-0 tonnes $\mathrm{ha}^{-1}$ & $18.913 \mathrm{~b}$ & $25.529 b$ & $32.613 \mathrm{~b}$ & $42.987 \mathrm{~b}$ & $53.478 \mathrm{~b}$ \\
\hline-10 tons $\mathrm{ha}^{-1}$ & $19.064 \mathrm{~b}$ & $26.236 \mathrm{~b}$ & $33.489 \mathrm{~b}$ & $44.293 \mathrm{~b}$ & $55.693 \mathrm{~b}$ \\
\hline - 20 tons ha ${ }^{-1}$ & $21.069 \mathrm{ab}$ & $31.351 \mathrm{ab}$ & $41.624 \mathrm{~b}$ & $53.931 \mathrm{ab}$ & $68.176 \mathrm{ab}$ \\
\hline-30 tons ha ${ }^{-1}$ & $23.889 \mathrm{a}$ & $38.622 \mathrm{a}$ & $55.376 \mathrm{a}$ & $71.082 \mathrm{a}$ & $85.844 \mathrm{a}$ \\
\hline \multicolumn{6}{|c|}{ EM4 Concentration } \\
\hline$-0 \mathrm{ml} \mathrm{L}-1$ & $19.847 \mathrm{a}$ & $29.087 \mathrm{a}$ & $37.438 \mathrm{a}$ & $49.482 \mathrm{a}$ & $60.902 \mathrm{a}$ \\
\hline$-10 \mathrm{ml}$ of $\mathrm{L}^{-1}$ & $20.612 \mathrm{a}$ & $30.678 \mathrm{a}$ & $41.725 \mathrm{a}$ & $53.608 \mathrm{a}$ & $67.233 \mathrm{a}$ \\
\hline$-20 \mathrm{ml}$ of $\mathrm{L}^{-1}$ & $21.733 \mathrm{a}$ & $31.538 \mathrm{a}$ & $43.163 \mathrm{a}$ & $56.130 \mathrm{a}$ & $69.258 \mathrm{a}$ \\
\hline
\end{tabular}

Table 3 shows that application of Tithonia diversifolia dose of 30 tons $\mathrm{ha}^{-1}$ significantly different to the treatment Tithonia diversifolia 0 tons $\mathrm{ha}^{-1}$ and 10 ton $\mathrm{ha}^{-1}$ but no significant effect on treatment of 20 tons $\mathrm{ha}^{-1}$, Treatment of 30 tons $\mathrm{ha}^{-1}$ have an average plant height the highest in 2 wap $(18.913$ $\mathrm{cm}), 3$ wap $(25.529 \mathrm{~cm}), 4$ wap $(32.613 \mathrm{~cm}), 5$ wap $(42.987 \mathrm{~cm})$ and 6 wap $(53.478 \mathrm{~cm})$ and treatment 0 tonnes ha-1 has a lowest plant height in 2wap (18.913 $\mathrm{cm}), 3$ wap $(25.529 \mathrm{~cm}), 4$ wap $(32.613 \mathrm{~cm}), 5$ wap $(42.987 \mathrm{~cm})$ and 6 wap $(53.478 \mathrm{~cm})$. This case is presumably because of nutrient content at a dose of 30 tons $\mathrm{ha}^{-1}$ more available to plants so that the plants sweet corn is getting nutrients $\mathrm{N}, \mathrm{P}$, and $\mathrm{K}$ while at doses of 0 tonnes ha ${ }^{-1}$ cause unavailability of nutrients from Tithonia diversifolia treatment. This is consistent with the statement (Lingga, 2001) that the availability of $\mathrm{N}, \mathrm{P}$ and $\mathrm{K}$ in a sufficient amount influence on a metabolism both plants vegetative and generative. This is also consistent with the results Hutomo et al., (2015), that application Tithonia diversifolia increase corn plant height. It is because the nitrogen in the compost Tithonia diversifolia can increase vegetative growth corn.

The use of green manure of $T$. diversifolia capable of delivering high growth on sweet corn crop increases. High treatment of Tithonia diversifolia dose at given such as 30 ton ha ${ }^{-1}$ further improve the high growth of sweet corn plants anyway. This is

\section{Number of leaves}

The results of analysis of variance test dosage and concentration Tithonia diversifolia EM4 indicates a variable number of leaves significant (Table 2) that was followed by a further test DMRT at $5 \%$ level can be seen in Table 4 . The treatment dose of 30 tons ha ${ }^{-1}$ Tithonia diversifolia significantly different to the treatment 0 tons ha ${ }^{-1}$ and 10 ton ha ${ }^{-1}$ but no significant effect on treatment of 20 tons $^{-1}$ (Table 4). Treatment 30 ton $\mathrm{ha}^{-1}$ has an average number of leaves at most that on average 3 wap. While on treatment 0 ton $\mathrm{ha}^{-1}$

Tabel 3. Effect of Tithonia diversifolia dose and concentration of EM4 to the average number of leaves of the plant on 3 and 4 wap

\begin{tabular}{|c|c|c|}
\hline \multirow{2}{*}{ Treatment } & \multicolumn{2}{|c|}{ Average } \\
\hline & 3 wap & 4 wap \\
\hline \multicolumn{3}{|l|}{ T. diversifolia Doses } \\
\hline-0 tons ha ${ }^{-1}$ & $4.2 b$ & $4.0 \mathrm{~b}$ \\
\hline-10 tons $\mathrm{ha}^{-1}$ & $4.4 \mathrm{~b}$ & $4.1 \mathrm{~b}$ \\
\hline-20 tons ha ${ }^{-1}$ & $4.9 \mathrm{ab}$ & $4.5 \mathrm{ab}$ \\
\hline - 30 tons $\mathrm{ha}^{-1}$ & $5.6 \mathrm{a}$ & $5.4 \mathrm{a}$ \\
\hline \multicolumn{3}{|l|}{ EM4 Concentration } \\
\hline$-0 \mathrm{ml} \mathrm{L}-1$ & $4.6 \mathrm{a}$ & $4.3 \mathrm{a}$ \\
\hline$-10 \mathrm{ml}$ of $\mathrm{L}^{-1}$ & $4.8 \mathrm{a}$ & $4.5 \mathrm{a}$ \\
\hline$-20 \mathrm{ml}$ of $\mathrm{L}^{-1}$ & $5.0 \mathrm{a}$ & $4.7 \mathrm{a}$ \\
\hline
\end{tabular}

Description: The figures followed the same letter in a column explaining no significant effect on DMRT at 5\% level. wap $=$ weeks after planting. 
Tabel 4. Effect of Tithonia diversifolia dose and concentration of EM4 to the mean stem ring of the plant at 2.3. 4. 5. and 6 wap.

\begin{tabular}{|c|c|c|c|c|c|}
\hline \multirow{2}{*}{ Treatment } & \multicolumn{5}{|c|}{ Average } \\
\hline & 2 wap & 3 wap & 4 wap & 5 wap & 6 wap \\
\hline \multicolumn{6}{|c|}{ T. diversifolia doses } \\
\hline 0 tons ha ${ }^{-1}$ & $2.98 \mathrm{~b}$ & $5.23 \mathrm{~b}$ & $7.04 \mathrm{~b}$ & $8.67 \mathrm{~b}$ & $10.23 \mathrm{~b}$ \\
\hline 10 tons $\mathrm{ha}^{-1}$ & $3.12 \mathrm{~b}$ & $5.34 \mathrm{~b}$ & $7.30 \mathrm{~b}$ & $9.66 \mathrm{~b}$ & $10.90 \mathrm{~b}$ \\
\hline 20 tons $\mathrm{ha}^{-1}$ & $3.56 \mathrm{~b}$ & $6.45 \mathrm{ab}$ & $9.12 \mathrm{~b}$ & $11.18 \mathrm{ab}$ & $12.60 \mathrm{ab}$ \\
\hline 30 tons $\mathrm{ha}^{-1}$ & $4.23 \mathrm{a}$ & $8.28 \mathrm{a}$ & $12.83 \mathrm{a}$ & $14.96 \mathrm{a}$ & $16.01 \mathrm{a}$ \\
\hline \multicolumn{6}{|c|}{ EM4 Concentration } \\
\hline $0 \mathrm{ml} \cdot \mathrm{L}^{-1}$ & $3.35 \mathrm{a}$ & $6.20 \mathrm{a}$ & $8.67 \mathrm{a}$ & $10.57 \mathrm{a}$ & $11.81 \mathrm{a}$ \\
\hline $10 \mathrm{ml} \cdot \mathrm{L}^{-1}$ & $3.48 \mathrm{a}$ & $6.26 \mathrm{a}$ & $9.06 \mathrm{a}$ & $11.51 \mathrm{a}$ & $12.66 \mathrm{a}$ \\
\hline $20 \mathrm{ml} . \mathrm{L}^{-1}$ & $3.35 \mathrm{a}$ & $6.55 \mathrm{a}$ & $9.48 \mathrm{a}$ & $11.81 \mathrm{a}$ & $12.84 \mathrm{a}$ \\
\hline
\end{tabular}

has an average number of leaves at least 3 wap i.e. at an average of 4.2 and 4 wap is 4.0 strands. This is presumably because the condition of the amount of nutrients at a dose of 30 tons $\mathrm{ha}^{-1}$ more available to plants and sweet corn as compared with the other treatments. Availability of nutrients easily absorbed and immediately used by especially in the formation of leaf crops (Nyakpa et al., 2013).

Sweet corn crop at a low dose treatment Tithonia diversifolia experiencing barriers to the formation of the leaves of plants, especially when the sweet corn treated with a dose of Tithonia diversifolia 0 ton ha ${ }^{-1}$. Putri (2011) also stated that the formation of the leaves on the plant strongly influenced by the availability of nutrients $\mathrm{N}$ and $\mathrm{P}$ on the medium available to plants. The more the number of leaves of sweet corn plants, the greater too broad leaves of the plant so that the process of photosynthesis will be higher thus increasing the number of leaves, plant height and trunk stem circumference. The growth of leaves of the plant will increase the length and width when the nutrients available to plants in sufficient quantity (Hakim et al., 1986). It is also stated that high dose of organic material can optimize the absorption of nutrients resulting in a growing fotosintat. $\mathrm{C} / \mathrm{N}$ ratio of green manure is very low but it is allegedly very quickly decompose, so the plants sweet corn significantly affect the number of leaves on 3 and 4 wap.

\section{Stem circumference}

Outcome analysis of variance test dose of Tithonia diversifolia and EM4 concentration shows a variable number of leaves significant (Table 2) that the results of a further test DMRT at 5\% level are shown in Table 5. There were significantly different to the treatment 0 ton ha ${ }^{-1}, 10$ tons ha $\mathrm{h}^{-1}$ and 20 ton ha 1 at 2 and 4 wap. Giving green manure weed Tithonia diversifolia 30 ton $\mathrm{ha}^{-1}$ significantly different to the treatment 0 tonnes ha $\mathrm{h}^{-1}$ and 10 ton $\mathrm{ha}^{-1}$ but no significant effect on treatment of 20 tons $\mathrm{ha}^{-1}$ at 3, 5 and 6 wap. Treatment of 30 tons ha ${ }^{-1}$ The plant produces stem circumference at 2 wap, 3 wap, wap 4, 5 and 6 wap wap when compared with other treatments, while giving treatment 0 tonnes $\mathrm{ha}^{-1}$ showed the smallest stem circumference of the plant. Stem circumference a treatment plant 30 ton $\mathrm{ha}^{-1}$ Tithonia diversifolia at 2 wap $(4.227 \mathrm{~mm}), 3$ wap
$(8,280 \mathrm{~mm}), 4$ wap $(12,829 \mathrm{~mm}), 5$ wap $(14.956$ $\mathrm{mm})$ and 6 wap $(16.011 \mathrm{~mm})$ higher than the treatment 0 tonnes ha $^{-1}$ at 2 wap $(2,979 \mathrm{~mm}), 3$ wap $(5,271 \mathrm{~mm}), 4$ wap $(7.036 \mathrm{~mm}), 5$ wap $(8.686 \mathrm{~mm})$ and 6 wap $(10.230 \mathrm{~mm})$.

\section{Greeness of leaves}

The high organic matter will optimize the process of absorption of nutrients and the more fotosintat results produced by the plant. Results fotosintat that many large stem circumference will increase the plant stem sweet corn.

The content of nutrients $\mathrm{N}, \mathrm{P}$ and $\mathrm{K}$ are owned Tithonia diversifolia was instrumental to the growth of sweet corn crops. $\mathrm{N}$ is a macro nutrient most needed by plants. According Fahmf et al., (2009), P is the limiting factor for the growth of the corn crop nutrient needs of plants, other than $\mathrm{P}$ already given in an amount calculated sufficient to support optimum growth.

In Table 6 shows that the administration of green manure weed Tithonia diversifolia 30 tons $\mathrm{ha}^{-1}$ differently to treatment 0 tons ha $\mathrm{h}^{-1}$ and 10 ton ha but no significant effect on treatment of 20 tons ha. Tithonia diversifolia treatment dose of 30 tons $\mathrm{ha}^{-1}$ produces an average level of the highest leaf greenness at 4 wap 34.769 and treatment doses of Tithonia diversifolia 0 ton ha ${ }^{-1}$ shows the average level of the green leaves of the plant lowest in 4 wap is 23.768. Level greenish leaf on sweet corn significantly different at 4 wap allegedly because the supply of nutrients from Tithonia diversifolia available for plants gradually or slowly available to

Table 5. Effect of the dose of Tithonia diversifolia and EM4 concentration on the average greenish level of plant leaves at $4 \mathrm{mst}$

\begin{tabular}{|c|c|}
\hline Treatment & Greenish \\
\hline $\begin{array}{l}\text { Tithonia diversifolia doses } \\
0 \text { tons ha } \mathrm{ha}^{-1} \\
10 \text { tons ha } \\
20 \text { tons } \mathrm{ha}^{-1} \\
30 \text { tons } \mathrm{ha}^{-1}\end{array}$ & $\begin{array}{l}23.768 \mathrm{~b} \\
20.768 \mathrm{~b} \\
25.816 \mathrm{ab} \\
34.769 \mathrm{a}\end{array}$ \\
\hline $\begin{array}{c}\text { EM4 Concentration } \\
0 \mathrm{ml} . \mathrm{L}^{-1} \\
10 \mathrm{ml} . \mathrm{L}^{-1} \\
20 \mathrm{ml} . \mathrm{L}^{-1} \\
\end{array}$ & $\begin{array}{l}25.092 \mathrm{a} \\
27.308 \mathrm{a} \\
26.422 \mathrm{a} \\
\end{array}$ \\
\hline
\end{tabular}


plants. It is also stated Damanik et al., (2011), which states some of the weaknesses of organic fertilizer is as follows: 1) low nutrient content; 2) relatively 1 difficult obtain in large quantities; 3 ) slowly available to plants and 4) transport and application costly because it is needed in large quantities. According Sinaga et al., (2014), nutrients $\mathrm{N}$ is needed for growth plant because it helps the process of photosynthesis. Through nutrient nitrogen would be the process of photosynthesis in the presence of chlorophyll. With the increase of photosynthesis then also increase the amount of chlorophyll of leaves, which chlorophyll derived from the element nitrogen.

\section{Effect of green manure Tithonia diversifolia and EM4 on Sweet Corn Crop}

The results of analysis of variance test treatment dose Tithonia diversifolia and EM4 indicates variables fresh weight of the plants, plant dry weight, the weight of cob Tanpe berkelobot, cob stem circumference and length of the cob were not significant (Table 2), the average yield of sweet corn can be seen in Table 6 it is suspected because of the availability of nutrients in weeks 5 and 6 wap is no longer available, it is also seen in a variable amount of sweet corn plant leaves that effect at week 3 and 4 wap, but on 5 and 6 wap no real effect. In addition to the number of leaves of the plant, the leaf greenness level variables also seen that the level of greenish leaves only real effect on 4 wap.

Table 6 shows that the higher the dose of Tithonia diversifolia it will increase the value of the average yield of sweet corn that is the plant fresh weight, dry weight of plants, heavy berkelobot Tanpe cob, cob stem circumference and length of the cob. This is due to the higher dose of Tithonia diversifolia, it will increase the availability of nutrients for plants.

EM4 concentration of no real effect because it is allegedly less than optimal storage EM4. EM4 storage are strongly advised to do storage at room temperature is low, so that the microorganisms contained in the EM4 not die. The weather at the time of spraying EM4 also greatly affected. Favorable weather conditions for spraying is in the late afternoon so that at night the microorganisms given in plants can be utilized. In research carried out when spraying EM4 rain in the research area, giving rise to the washing on the EM4 sprayed, in addition to the slopes used are also influential. When it rains down on sloping land, it will cause erosion so that the nutrients contained in the map is reduced. Table 7 shows the higher concentration of EM4 then tend to the higher average plant fresh weight, dry weight of plants without husk, cob weight, stem circumference and length of the cobs of sweet corn plants

\section{CONCLUSIONS}

Combination of Tithonia diversifolia dose treatment and EM4 no effect on the growth and yield of sweet corn. The dosages of Tithonia diversifolia 30 ton $\mathrm{ha}^{-1}$ at 2, 3, 4, 5, and 6 weeks after planting showed a row of plant height of $23.9 \mathrm{~cm} ; 38.6 \mathrm{~cm}$; $55.4 \mathrm{~cm} ; 71.1 \mathrm{~cm}$ and $85.8 \mathrm{~cm}$, number of leaves on the 3rd and 4th highest wap strands 5.4 and 5.6, the largest stem stem circumference at 2, 3, 4, 5 and 6 wap with of $4.2 \mathrm{~mm} ; 8.3 \mathrm{~mm} ; 12.8 \mathrm{~mm} ; 15 \mathrm{~mm}$ and $16 \mathrm{~mm}$, and leaf greenness at the highest level 4 wap of 34.8. Concentration of EM4 treatment had no effect on the growth and yield of sweet corn

\section{REFERENCES}

Dahlianah, I. 2004. Pupuk hijau salah satu pupuk organik berbasis ekologi dan berkelanjutan (Green manure one based organic fertilizers and sustainable ecology). Klorofil. 9 (2): 54-56.

Damanik, B.M.M., Bachtiar, F. Sarifuddin and H. Hamida. 2011. Kesuburan Tanah dan Pemupukan (Soil Fertility and Fertilization). USU Press, Medan. Hal. 20-25.

Hakim, N., M. Y. Nyakpa, A. M. Lubis, S. G. Nugroho, M. A. Diha, G. B. Hong dan H. H. Bailey. 1986. Dasar-dasarilmu tanah (The basics of soil science). Universitas Lampung. Lampung.

Hutomo I. P., Mahfudz, dan S. Laude. 2015. Pengaruh Pupuk Hijau Tithonia Diversifolia terhadap Pertumbuhan dan Hasil Tanaman Jagung (Zea Mays L.) (Effect of green manure Tithonia diversifolia on the Growth and Yield of Maize (Zea mays L.) ). Jurnal e-J.Agrotekbis 3 (4):475-481.

Tabel 6. Effect of Tithonia diversifolia dose and concentration of EM4 to mean fresh weight of the plants. plant dry weight. weight without berkelobot cob. cob stem circumference and length of the cob

\begin{tabular}{|c|c|c|c|c|c|}
\hline Treatment & $\begin{array}{l}\text { Plant fresh } \\
\text { weight }(\mathrm{g})\end{array}$ & $\begin{array}{c}\text { Plant dry } \\
\text { weight }(\mathrm{g})\end{array}$ & $\begin{array}{l}\text { No husk cob } \\
\text { weight (g) }\end{array}$ & $\begin{array}{c}\text { Cob stem cir- } \\
\text { cumference } \\
(\mathrm{mm})\end{array}$ & $\begin{array}{l}\text { Cob length } \\
\text { (cm) }\end{array}$ \\
\hline \multicolumn{6}{|l|}{ T. diversifolia doses } \\
\hline 0 tons $\mathrm{ha}^{-1}$ & 69.34 & 20.91 & 49.57 & 27.47 & 10.54 \\
\hline 10 tons $\mathrm{ha}^{-1}$ & 93.99 & 29.66 & 69.69 & 30.93 & 12.66 \\
\hline 20 tons ha ${ }^{-1}$ & 104.27 & 30.83 & 71.17 & 31.99 & 12.69 \\
\hline 30 tons ha ${ }^{-1}$ & 138.36 & 42.86 & 108.14 & 35.99 & 14.23 \\
\hline \multicolumn{6}{|l|}{ EM4 doses } \\
\hline $0 \mathrm{ml} . \mathrm{L}^{-1}$ & 98.81 & 29.92 & 69.76 & 29.84 & 12.02 \\
\hline $10 \mathrm{ml} . \mathrm{L}^{-1}$ & 99.07 & 30.61 & 73.18 & 32.09 & 12.34 \\
\hline $20 \mathrm{ml} \cdot \mathrm{L}^{-1}$ & 106.59 & 32.67 & 81.00 & 32.86 & 13.23 \\
\hline
\end{tabular}


Lestari, S. A. D., 2016. Pemanfaatan paitan (Thitonia diversifolia) sebagai pupuk organik pada Tanaman Kedelai (Utilization of Tithonia diversifolia as organic fertilizer on soybean plants). Jurnal IPTEK Tanaman Pangan. 11 (1).

Lingga. 2001. Petunjuk Penggunaan Pupuk (Manual of Fertilizer Utilization). Penebar Swadaya, Jakarta. Hal 86-88.

Martajaya, M., L. Agustina, dan Syekhfani. 2010. Metode budidaya organik tanaman jagung manis di tlogomas Malang (Methods of organic cultivation of sweet corn plants in Tlogomas Malang). JurnalPembangunan dan Alam Lestari.1(1): 1-8

Naldo, R. A., 2011. Sifat fisika ultisol limau manis tiga tahun setelah pemberian beberapa jenis pupuk hijau (Physical properties of ultisol of after three years of the granting of some types of green manure). Skripsi. Fakultas Pertanian. Universitas Andalas.

Nugroho, Y. A., Y. Sugito, L. Agustina dan Soemarmo. 2013. Kajian penambahan dosis beberapa pupuk hijau dan pengaruhnya terhadap pertumbuhan tanaman selada (Lactuca sativa L.) (Study of increasing doses several green manure and its influence on the growth of lettuce plants (Lactuca sativa L.)). Jurnal Exp. Life Sci. 3 (2) ISSN. 2087-2852 E-ISSN. 2338-1655.

Nurmegawati, Yahumri dan Afrizon, 2015. Rekomendasi pupuk tanaman jagung dan kedelai di Kabupaten Kaur, Bengkulu (Fertilizer recommendation of corn and soybean crop in Kaur Regency of Bengkulu). J. Pros. Sem Nas MasyBiodiv Indon. 1 (4): 914-917.

Nyakpa,Y. M., A. A. Lubis, M.A. Pulung, A. G. Amrah, A. Munawar, B. H. Go, dan N. Hakim. 2003. Kesuburan Tanah (Soil Fertility). Universitas Lampung. Lampung.

Purnama, K. 1998. Pengaruh konsentrasi Effective Microorganisme-4 (EM4) dan jenis sumber bahan organik terhadap pertumbuhan dan hasil tanaman bawang putih (Allium sativum L.) dataran rendah varietas lokal sanur (Effects of Effective concentrations of microorganisms-4 (EM4) and the type of source of organic material on the growth and yield of garlic (Allium sativum L.) lowland variety of local sanur). Skripsi. Fakultas Pertanian. Universitas Udayana. Bali.

Putri, H. A. 2011. Pengaruh pemberian beberapa konsentrasi pupuk organik cair lengkap (POCL) bio sugih terhadap pertumbuhan dan hasil tanaman jagung manis (Zea mays saccharata Sturt) (The effect of several concentrations of complete liquid organic fertilizer $(\mathrm{POCl})$ bio sugih on the growth and yield of sweet corn (Zea mays saccharata Sturt.)). Skripsi. Fakultas Pertanian. Universitas Andalas Padang.

Sigalingging, D. H. 2016. Perbedaan waktu kompetisi gulma pada pertumbuhan dan hasil tanaman jagung manis (Zea mays saccharataSturt) di pertanian organik (The time difference weed competition on the growth and yield of sweet corn (Zea mays saccharata Sturt) in organic farming). Skripsi. Fakultas pertanian. Universitas Bengkulu.

Simatupang, P. 2014. Pengaruh dosis kompos paitan (Tithonia diversifolia) terhadap pertumbuhan dan hasil kol bunga pada sistem pertanian organik (The effect of compost dosages of Tithonia diversifolia on the growth and yield of cauliflower on the organic farming system). Skripsi. Fakultas pertanian. Universitas bengkulu.

Sinaga, P., Meiriani dan Y. Hasanah. 2014. Respons pertumbuhan dan produksi kailan (Brassica Oleraceae L.) pada pemberian berbagai dosis pupuk organik cair paitan (Tithonia Diversifolia) (Response of growth and petsai production (Brassica oleracea L.) at several doses of liquid organic fertilizer of Tithonia diversifolia. Jurnal Online Agroekoteknologi 2 (4) :1584-1588. 